\title{
Accountingonderzoekers over Enron
}

\author{
Jan van Helden
}

De Enronaffaire ligt nog vers in ieders geheugen en nu al is hierover een themanummer van een heus wetenschappelijk tijdschrift verschenen. De eerste signalen over de problemen bij Enron dateren van oktober 2001 en enkele maanden later kwam informatie naar buiten over de ware aard

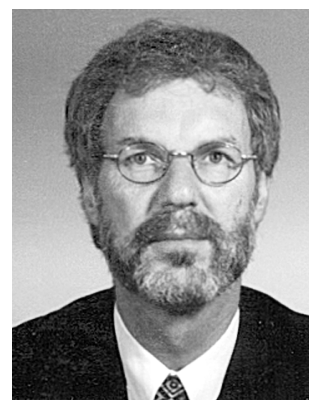
en omvang van deze problemen. Het gezaghebbende Amerikaanse tijdschrift The Journal of Accounting and Public Policy (JAPP) wijdde haar zomereditie van 2002 vrijwel geheel aan de Enronaffaire. Deze editie moet binnen het bestek van een paar maanden in elkaar zijn gezet. Als men bedenkt dat de doorlooptijd van artikelen voor een internationaal wetenschappelijk tijdschrift normaliter ongeveer twee jaren bedraagt, getuigt dit van een alertheid die zijn weerga niet kent in de wereld van de 'echte' economische wetenschap.

Hier wil ik vooral stilstaan bij de twee langere artikelen uit JAPP, die ik heb gelezen in de verwachting daarin achtergronden en overwegingen aan te treffen die in de populaire pers zijn onderbelicht.

Abdel-khalik (2002) pleit in zijn artikel voor een verandering van de corporate-governancestructuur bij de selectie, beloning en het ontslag van auditors. Bestaande en potentiële aandeelhouders moeten erop kunnen vertrouwen dat de openbaar gemaakte informatie over de door het management van een onderneming behaalde resultaten 'fair and faithful' is. Auditors spelen de belangrijkste rol om dit vertrouwen te schragen. Maar dan moeten auditors aan drie voorwaarden voldoen: (1) zij moeten onafhankelijk

Prof. Dr. G.J. van Helden is hoogleraar management accounting aan de Economische Faculteit van de Rijksuniversiteit Groningen; hij is tevens lid van de kernredactie van het MAB. zijn van het management over wier prestaties een oordeel wordt uitgesproken, (2) zij moeten sceptisch staan tegenover de wijze waarop het management zijn resultaten presenteert, en (3) hun oordeel moet zijn gebaseerd op professioneel ontwikkelde en getoetste accounting- en auditingregels.

De huidige wijze waarop auditors worden aangetrokken, beloond en eventueel ontslagen, voldoet niet aan deze voorwaarden. In de praktijk zijn auditors namelijk primair de cliënt van het management, terwijl zij zouden moeten fungeren als de agent van of zelfs de waakhond voor de aandeelhouders. Het zijn de managers die auditors selecteren, vaststellen welke taken ze moeten uitvoeren, hoeveel daarvoor wordt betaald en op grond waarvan de relatie met de onderneming kan worden beëindigd. Deze anomalie in de corporate governance wordt versterkt indien de auditor tevens adviesopdrachten voor de onderneming, en dus primair voor het management, vervult. Abdelkhalik komt tot de conclusie dat aan deze ongewenste situatie een einde kan worden gemaakt indien auditors worden benoemd, beloond en ontslagen door een orgaan dat volledig onafhankelijk functioneert ten opzichte van het management van de onderneming. Hij introduceert hiertoe het Shareholders' Board of Trustees (SBT), waarvan de leden geen enkele binding hebben, laat staan personele unies vormen met het topmanagement. Een SBT moet handelen in naam van de aandeelhouders en is ook alleen aan hen verantwoording verschuldigd.

Waar dit artikel ophoudt, wordt het juist spannend. De interessante vraag is immers wie in een SBT zitting moeten nemen. Onafhankelijkheid, deskundigheid en bedrijfsspecifieke expertise gaan namelijk moeilijk samen. Een ex-bestuurder of ex-commissaris van de onderneming heeft wel bedrijfsspecifieke expertise, maar is niet onafhankelijk en vaak ook niet deskundig genoeg. Een accountant van een andere 
accountantsonderneming dan de controlerend accountant is wel deskundig, maar mist waarschijnlijk bedrijfsspecifieke kennis. En prestigieuze buitenstaanders zonder auditingachtergrond beschikken vaak over te weinig deskundigheid om zo'n functie goed te vervullen. Of zou een SBT moeten worden samengesteld uit personen die ieder voor zich slechts een of twee van de genoemde kwalificaties bezitten?

Het tweede artikel van Benston en Hartgraves (2002) bevat een analyse van het zogenaamde 'Powers report', dat naar aanleiding van de Enronaffaire is opgesteld. Hun analyse spitst zich toe op zes onderwerpen. Ten eerste komt aan de orde het achterwege blijven van consolidatie door Enron van SPE's (Special Purpose Entities), waardoor verliezen en schulden onzichtbaar bleven voor beleggers. Bij veel van deze SPE's bestonden de belangrijkste activa uit Enronaandelen, terwijl Enron garant stond voor hun leningen. Dit betekent dat de risico's over de activiteiten van zulke SPE's vrijwel geheel berusten bij Enron zelf. Ten tweede werden verkoopopbrengsten van niet-geconsolideerde, maar materieel wel door Enron gecontroleerde SPE's behandeld als 'arm length transactions'. Ten derde betaalden SPE's aan Enron bedragen voor garantstellingen bij verschafte leningen of voor te verrichten managementactiviteiten, die betrekking hadden op toekomstige perioden. Deze toekomstige opbrengsten werden door Enron evenwel geboekt als huidige opbrengsten. Ten vierde maakte Enron zich schuldig aan 'fair value accounting' van handelsinvesteringen die waren gebaseerd op dubieuze cijfers. Ten vijfde bleek Enron het verbod om waardestijgingen van eigen aandelen als winsten te boeken, te omzeilen door deze via de SPE's wel als winsten te boeken. Ten slotte bezondigde Enron zich aan een inadequate verantwoording (disclosure) van transacties met verbonden partijen. Sommige topfiguren, zoals CFO Fastow, trokken namelijk aan de touwtjes bij zowel Enron als diverse SPE's en hadden aanzienlijk financieel profijt van transacties tussen beide, zonder dat daarover werd gerapporteerd.

We beperken ons hier verder tot Benston en Hartgraves' beoordeling van de door Arthur Andersen (AA, de huisaccountant van Enron) verrichte werkzaamheden. AA wordt verweten US GAAP in bepaalde gevallen slechts in formele zin te hebben gebruikt, terwijl men had moeten weten dat accountingpraktijken bij Enron in materiële zin daarmee strijdig zijn. Dit geldt bijvoorbeeld voor het buiten de boeken van Enron houden van SPE's. Formele strijdigheid met US GAAP en GAAS werd door AA genegeerd in het geval van transacties door verbonden partijen die nauw met Enron waren verbonden. Bovendien bleek AA, nu in een adviseursrol, nauw betrokken bij de ontwikkeling van allerlei gecompliceerde financiële constructies tussen Enron en deze SPE's.

Over de vraag waarom AA zo'n dubieuze rol speelde in het debacle bij Enron geven Benston en Hartgraves diverse verklaringen. De eerste kan duiden op toeval: ondeskundig en daardoor foutief handelen van de betrokken accountants. Erg overtuigend klinkt dat niet. Dat geldt wel voor enkele andere verklaringen: de lange duur van de relatie tussen AA en Enron (bedrijfsblindheid, te weinig distantie) en het voor lief nemen van twijfelachtige accountingpraktijken in het belang van de continuering van de financieel aantrekkelijke relatie met Enron. Daarnaast wijzen Benston en Hartgraves erop dat Enron in de loop van de tijd evolueerde van een energieproducent en -distributeur tot een conglomeraat waarin financiële constructies en innovatieve activiteiten een hoofdrol gingen spelen. Betwijfeld wordt of AA bij het inzetten van zijn accountants voldoende heeft ingespeeld op deze gedaantewisseling van zijn opdrachtgever.

De analyse van Benston en Hartgraves is voer voor de accounting- en auditingprofessie. Dat aansprekende aantijgingen aan het adres van Enron en AA - in een populair blad las ik termen als wildplassen, naaien en graaien - achterwege blijven, doet daaraan niets af. Echte wetenschap kan wel zonder LPF-taal.

Mijn conclusie luidt dat het artikel van Abdel-khalik niet zou hebben misstaan in Het Financieele Dagblad, zij het zonder deftige termen als 'agency costs' en 'residual claimants'. Het artikel van Benston en Hartgraves daarentegen is wel van 'JAPP-niveau', hoewel het deels overlapt met een in het juninummer van MAB verschenen artikel van Langendijk en Van Praag (2002). Dus ook het MAB reageerde bijzonder alert op de Enronaffaire.

\section{Literatuur}

\footnotetext{
Abdel-khalid, A.R., (2002), Reforming corporate governance post Enron: Shareholders' Board of Trustees and the Auditor, in: Journal of Accounting and Public Policy, Vol. 21, no. 2, pp. 97-103.

Benston, G.J. en A.L. Hartgraves, (2002), Enron: what happened and what we can learn from it?, in: Journal of Accounting and Public Policy, Vol. 21, no. 2, pp. 105-127.

Langendijk, H.P.A.J. en B.J. van Praag, (2002), De externe verslaggeving van Enron met betrekking tot verbonden partijen, in het bijzonder special purpose entities, in: Maandblad voor Accountancy en Bedrijfseconomie, Jrg. 76, nr. 6, pp. 253-262.
} 